Endocrinol. Japon. 1987, 34 (2), 309-312

\title{
NOTE
}

\section{Somatostatin Suppresses Plasma Aldosterone Concentration in a Case of Bartter's Syndrome}

\author{
Hirofumi SHIGETA, Naohiro TASAKI, Seiji KITAZUMI, \\ YoshiHIRo KITAGAWA, KoJi NAKANO, TAKaHIRo KANATSUNA \\ AND MOTOHARU KONDO
}

First Department of Internal Medicine, Kyoto Prefectural University of Medicine, Kawaramachi-Hirokoji, Kamikyo-ku, Kyoto 606, Japan

\begin{abstract}
The study was conducted to examine the effect of somatostatin on activated renin-angiotensin-aldosterone system in a case of Bartter's syndrome. After 60 minutes of $500 \mu \mathrm{g}$ of somatostatin infusion, the plasma aldosterone concentration was reduced from the basal level of $250 \mathrm{pg} / \mathrm{ml}$ to $140 \mathrm{pg} / \mathrm{ml}$, whereas plasma renin activity remained at the basal level. This result suggests that somatostatin may specifically inhibit aldosterone secretion in Bartter's syndrome and the agent can be applied to a treatment of this syndrome.
\end{abstract}

The application of somatostatin as a therapeutic agent is still limited to a few clinical trials such as in treating unstable diabetes, acromegaly and functioning isletcell tumor, though the peptide suppresses the release of several hormones (Reichlin, 1983). Recently, Jones et al. (1984) reported that the increase in aldosterone due to exogenous angiotensin II and orthostasis were significantly attenuated by somatostatin. The present study was made to examine whether somatostatin administration suppresses the accelerated renin-angiotensin-aldosterone system in a case of Bartter's syndrome.
Materials and Methods

\section{Subject}

A 24-year-old female was admitted to our department because of weakness. Her diagnosis of Bartter's syndrome was confirmed by hypopotassemia, metabolic alkalosis, normotension, hyperreninemia, hyperaldosteronism, blunted pressor response to angiotensin II and hyperplasia of juxtaglomerular cells revealed by renal biopsy. She also had no history of chronic vomiting, diarrhea or habitual use of laxatives or diuretics. Her height was $147 \mathrm{~cm}$ and body weight was $31 \mathrm{~kg}$. Table 1 shows the laboratory findings at the start of the experiment.

\section{Infusion test \\ One week before the experiment, the patient was hospitalized and placed on a fixed sodium $(150 \mathrm{mEq} /$ day $)$ and potassium $(50 \mathrm{mEq} /$ day $)$ diet with oral potassium supplement $(72 \mathrm{mEq} /$ day $)$.}


Table 1. Laboratory findings at the start of the experiment

\begin{tabular}{clll}
\hline \hline Urinalysis & \multicolumn{2}{l}{ Blood chemistry } \\
pH & 9.0 & $\mathrm{Na}$ & $132 \mathrm{mEq} / 1$ \\
protein $(-)$ & $\mathrm{K}$ & $1.7 \mathrm{mFq} / 1$ \\
glucose $(-)$ & BUN & $8 \mathrm{mg} / \mathrm{dl}$ \\
CBC & & Creatinine & $0.7 \mathrm{mg} / \mathrm{dl}$ \\
$\mathrm{Hb}$ & $16.2 \mathrm{~g} / \mathrm{dl}$ & T. Protein & $6.3 \mathrm{~g} / \mathrm{dl}$ \\
$\mathrm{RBC}$ & $562 \times 10^{4} / \mathrm{mm}^{3}$ & Albumin & $3.5 \mathrm{~g} / \mathrm{dl}$ \\
$\mathrm{WBC}$ & $9400 / \mathrm{mm}^{3}$ & FBS & $118 \mathrm{mg} / \mathrm{dl}$ \\
Platelet & $61.4 \times 10^{4} / \mathrm{mm}^{3}$ & GOT & $27 \mathrm{KU}$ \\
& & GPT & $18 \mathrm{KU}$ \\
\hline
\end{tabular}

In the control study, the patient was infused with $50 \mathrm{ml}$ of physiological saline solution for 60 minutes through an antecubital vein using a constant-infusion pump. On the next day, she was given $500 \mu \mathrm{g}$ of somatostatin in $50 \mathrm{ml}$ saline solution in the same manner. The infusions were started at 9 a.m. after more than one hour of bed rest in a fasting state. Venous blood samples were obtained from the opposite cubital vein through an indwelling catheter at $-15,0,15$, $30,45,60$ and 90 minutes for the measurement of the plasma aldosterone concentration (PAC) and plasma renin activity (PRA). Blood samples were also collected at $0,30,60$ and 90 minutes for the measurement of serum immunoreactive insulin (IRI), plasma ACTH, serum sodium and potassium. PAC, PRA, ACTH and IRI were determined by RIA with a Gamma Coat PRA kit (Travenol Japan Co., Ltd., Japan), Aldosterone-RIA kit (Dinabot Co., Ltd., Japan), ACTH RIA kit (C.I.S.) (Midori Juji, Japan) and Insulin RIA kit (Eiken Immunological Laboratory, Japan), respectively. The serum sodium and potassium concentration were measured with an autoanalizer. Blood pressure and heart rate were measured every five minutes.

The subject was fully informed of this study and consented to participate in the experiment. No symptoms or signs were observed during the experiment.

\section{Results}

Figure 1 shows the changes in PAC and PRA during the saline control and the somatostatin infusions. PAC decreased gradually during the somatostatin infusion

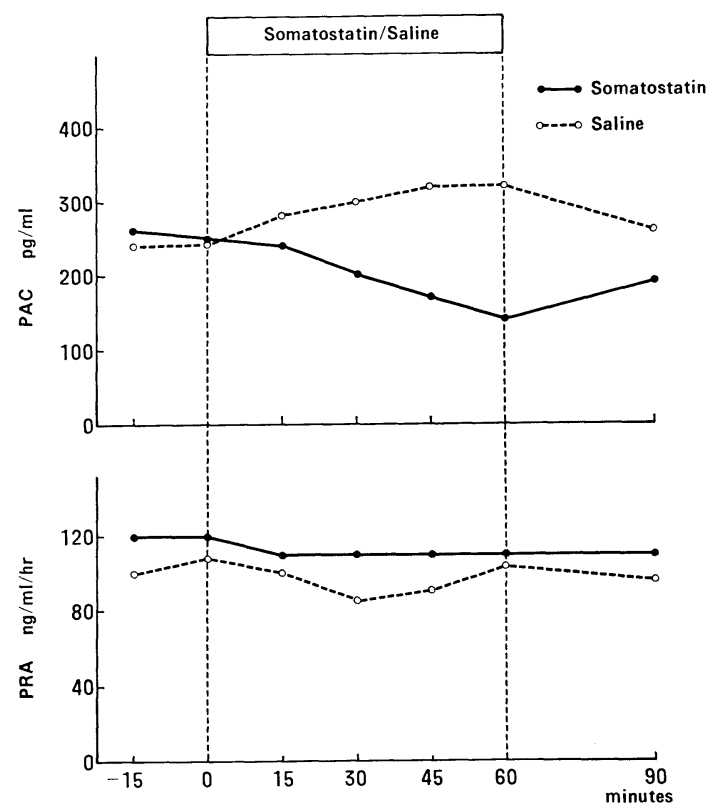

Fig. 1. Responses of PAC and PRA during somatostatin $(500 \mu \mathrm{g} / \mathrm{hr})(O)$ and saline infusion $(\bigcirc)$.

from the basal $250 \mathrm{pg} / \mathrm{ml}$ to $140 \mathrm{pg} / \mathrm{ml}$ at 60 minutes and rose 30 minutes after the cessation of the infusion, whereas PAC increased slightly during the saline infusion. On the other hand, PRA was affected little by either the saline or the somatostatin.

Table 2 shows the other variables during the saline and somatostatin infusions. IRI decreased markedly, but plasma ACTH, serum sodium and serum potassium were not affected by the somatostatin.

Blood pressure and heart rate did not change during the infusions.

\section{Discussion}

The present study demonstrated that somatostatin inhibits hypersecretion of aldosterone without affecting increased PRA in a case of Barrter's syndrome. Since none of the variables such as serum sodium, potassium, plasma ACTH and blood pressure 
Table 2. Responses of IRI, ACTH, Na and $\mathrm{K}$ during somatostatin and saline infusion

\begin{tabular}{lllrrrr}
\hline & & & 0 & 30 & 60 & 90 minutes \\
\hline Somatostatin & IRI & $\mu \mathrm{U} / \mathrm{ml}$ & 2.4 & 1.7 & undetectable & 20.8 \\
& $\mathrm{ACTH}$ & $\mathrm{pg} / \mathrm{ml}$ & 82 & 88 & 93 & 100 \\
& $\mathrm{Na}$ & $\mathrm{mEq} / \mathrm{l}$ & 129 & 130 & 128 & 130 \\
& $\mathrm{~K}$ & $\mathrm{mEq} / \mathrm{l}$ & 1.7 & 1.6 & 1.7 & 1.7 \\
\hline \multirow{2}{*}{ Saline } & $\mathrm{IRI}$ & $\mu \mathrm{U} / \mathrm{ml}$ & 4.0 & 6.9 & 5.3 & 4.6 \\
& $\mathrm{ACTH}$ & $\mathrm{pg} / \mathrm{ml}$ & 68 & 64 & 75 & 82 \\
& $\mathrm{Na}$ & $\mathrm{mEq} / \mathrm{l}$ & 129 & 131 & 128 & 132 \\
& $\mathrm{~K}$ & $\mathrm{mEq} / \mathrm{l}$ & 2.2 & 2.0 & 1.9 & 1.8 \\
\hline
\end{tabular}

changed in this experiment, they apparently didn't play a role in the inhibition of PAC. It is therefore probable that the attenuation of PAC was a result of the direct action of somatostatin on the adrenal gland.

Some previous reports have demonstrated the effect of somatostatin on the reninangiotensin-aldosterone system. Though somatostatin is thought to suppress this system in general, its effects on PRA and PAC are different in each report. Rosenthal et al. (1976) showed that somatostatin inhibited hyperreninemia induced by a frosemide. Gomez-Pan et al. (1976) also showed that this agent reduced the concentration of PRA but did not affect PAC under the condition of active renin secretion following pretreatment with frosemide. On the other hand, Jones et al. (1984) showed that the increase in aldosterone after exogenous angiotensin II administration was inhibited by somatostatin, whereas PRA remained unchanged. It also should be noted that some pretreatments were performed in them to activate the renin-angiotensin-aldosterone system, because the subjects of these studies were healthy volunteers.

The results of the present study do not conflict with those of Jones et al., which were supported by in vitro studies by Aguilera et al. $(1981 ; 1982)$. They demonstrated that somatostatin specifically inhibited the aldosterone response to angiotensin II by interfering with the specific high-affinity receptors. Though the mechanism responsi- ble for the present results is still unclear, it was suggested that increased secretion of aldosterone due to the pathological state such as Bartter's syndrome could also be inhibited by somatostatin. It remains uncertain whether the present results relate to the pathophysiology of Bartter's syndrome or to the character of somatostatin as a local regulator.

In the present study, serum potassium did not increase as expected during one hour infusion of somatostatin. Part of the explanation for this result may be the necessity for a time lag in aldosterone action in the kidney, since generally the renal effect of aldosterone begins one half to two hours after administration. This time lag may reflect the process of steroid-receptor interaction, RNA transcription and protein synthesis (Bondy, 1985), so that the increase in potassium might be expected in our case when suppression of PAC were maintained.

Since the reports of Gill et al. (1976) and Verberckmoes et al. (1976), the indomethacin treatment has been effective in many cases with Bartter's syndrome in suppressing the renin-angiotensin-aldosterone system but has failed in some cases. The present study suggests the feasibility of somatostatin treatment in some cases of this syndrome. The short half-life of the somatostatin preparation has prevented the practical use of this native peptide. Recently a long-acting somatostatin analogue became available for clinical use and its usefulness 
in the treatment of acromegaly was reported (Bauer et al., 1982; Lamberts et al., 1985). Lamberts et al. reported that neither malabsorption nor steatorrhea was detected and the inhibitory effect of the analogue on insulin secretion was short-lived. Whenever somatostatin is used as a therapeutic agent, mention should be made of possible side effects. It would be of interest, however, to consider the clinical application of somatostatin in the treatment of Bartter's syndrome, though the effects of long-term administration remain to be studied.

\section{Acknowledgements}

The authors are grateful to Associate Professor Harano of Shiga University of Medical Science for his generous gift of a somatostatin preparation.

\section{References}

Aguilera, G., J. P. Harwood and K. J. Catt (1981). Somatostatin modulates effects of angiotensin II in adrenal glomerulosa zone. $\mathrm{Na}$ ture 292, 262-263.

Aguilera, G., D. S. Parker and K. J. Catt (1982). Characterization of somatostatin receptors in the rat adrenal glomerulosa zone. Endocrinology 111, 1376-1384.

Bauer, W., U. Briner, W. Doepfner, R. Haller, R. Huguenin, P. Marbach, T. J. Petcher and J. Pless (1982). SMS 201-995: A very potent and selective octapeptide analogue of somatostatin with prolonged action. Life Sci. 31,
1133-1140.

Bondy, P. K. (1985). Disorders of adrenal cortex. In: The Textbook of Endocrinology (J. D. Wiloson and D. W. Foster ed.), W. B. Saunders, Philadelphia. pp. 816-890.

Gill, J. R., J. C. Frolich, R. E. Bowden, A. A. Taylor, H. R. Keiser, H. W. Seyberth, J. A. Oates and F. C. Bartter (1976). Batter's syndrome: a disorder characterized by high urinary prostaglandins and a dependence of hyperreninemia on prostaglandin synthesis. Am. $J$. Med. 61, 43-51.

Gomez-Pan, A., M. H. Snow, D. A. Piercy, V. Robson, R. Wilkinson, R. Hall, D. C. Evered, G. M. Besser, A. V. Schally, A. J. Kastin and D. H. Coy (1976). Actions of growth hormone-release inhibiting hormone (Somatostatin) on the renin aldosterone system. J. Clin. Endocrinol. Metab. 43, 240-243.

Jones, C. R., J. A. Millar, C. Lawrie, D. J. Sumner and J. L. Reid (1984). Specific inhibition of aldosterone responses to endogenous and exogenous angiotensin II by somatostatin. Clin. Endocrinol. 21, 279-284.

Lamberts, S. W. J., P. Uitterlinden, L. Verschoor, K. J. van Dongen and E. del Pozo (1985). Long-term treatment of acromegaly with the somatostatin analogue SMS 201-995. N. Engl. J. Med. 313, 1576-1580.

Reichlin, S. (1983). Somatostatin. N. Engl. J. Med. 30, 1495-1501, 1556-1563.

Rosenthal, J., S. Raptis, F. Escobar-Jimenez and E. F. Pfeiffer (1976). Inhibition of frosemideinduced hyperreninaemia by growth-hormone release-inhibiting hormone in man. Lancet ii, 772-774.

Verberckmoes, R., B. van Damme, J. Clement, A. Amery and P. Michielsen (1976). Bartter's syndrome with hyperplasia of renomedullary cells: successful treatment with indomethacin (1976). Kidney International 9, 302-307. 